\title{
Bacillus anthracis as a biological warfare agent: infection, diagnosis and countermeasures
}

\author{
Pohanka M \\ Faculty of Military Health Sciences, University of Defense, Hradec Kralove, Czech Republic. \\ miroslav.pohanka@gmail.com
}

\begin{abstract}
AIM: Bacillus anthracis is a causative agent of zoonotic anthrax disease. In the last years, significant progress in therapy and diagnosis of anthrax was made. Concurrently, knowledge about anthrax progression, molecular pathology and release of anthrax toxin during the disease has improved. This review covers the recent progress in this field.

METHODS: In this review, specifications of $B$. anthracis, anthrax disease, medical and biomedical countermeasures and diagnostic tools were surveyed. The actual literature was summarized and relevance of the microorganism as a biological warfare agent and the ways how to reduce its impact including therapeutic protocols were written and discussed.

RESULTS: Currently, the microorganism is considered one of the top biological warfare agents due to lethality, long term stability of spores, easy dissemination and production. The recent research is focused on countermeasures suitable for reduction of consequences by a misuse of the microorganism in form of biological weapon (Tab. 3, Fig. 1, Ref. 101). Text in PDF www.elis.sk.

KEY WORDS: anthrax, bacillus anthracis, biological warfare agent, biological weapon, detection, diagnosis, infection, therapy.
\end{abstract}

\section{Introduction}

Bacillus anthracis is a well-known biological warfare agent and many people without experience in the field of biological weapons probably call back the knowledge about $B$. anthracis as it was presented in popularized fiction stories and movies. Though B. anthracis is a very dangerous biological agent and the disease anthrax epidemic can be followed by a high mortality, there is a higher number of microorganisms that can represent relevant military threat or at least could be used by a military or a terrorist under some circumstances. Along with the other biological warfare agents, it is named in the international convention called "The Convention on the Prohibition of the Development, Production and Stockpiling of Bacteriological (Biological) and Toxin Weapons and on their Destruction" from 1972.

Thought the international convention contains the list of microorganism species counted in dozens, only few of them are considered seriously dangerous and relevant as a tool in a warfare attack. The category " $\mathrm{A}$ " according to the Center for Disease Control

Faculty of Military Health Sciences, University of Defense, Hradec Kralove, Czech Republic

Address for correspondence: M. Pohanka, RND, PhD, DSc, Faculty of Military Health Sciences, University of Defense, Brno, Trebesska 1575, CZ-500 01 Hradec Kralove, Czech Republic.

Acknowledgements: A long-term organization development plan "Medical Aspects of Weapons of Mass Destruction" and Specific research funds (Faculty of Military Health Sciences, University of Defense, Czech Republic) is gratefully acknowledged. and Prevention (Atlanta, GA, United States) is frequently used for the indication of the most dangerous biological warfare agents. $B$. anthracis is considered as one of the top biological warfare agents from the A category. Beside B. anthracis, microorganisms Francisella tularensis and Yersinia pestis, viruses Variola major and hemorrhagic fevers viruses like Ebola, Lassa, Machupo and Marburg, and Clostridium botulinum with its botulinum toxin are in the same category (1-5). Beside of biological warfare agents, there is a high number of microorganisms that are able to cause serious infections, but they are not considered as biological warfare agents because of their slow limited tactical impact. Toxoplasmosis or AIDS (Acquired Immuno-Deficiency Syndrome) can be exampled as relevant diseases, but their progression is slow and their spreading requires specific conditions (6-9). They are not considered a significant military or terrorist threat due to the above mentioned reasons. Anthrax is another story because of high mortality and fast disease progression. Relevance of B. anthracis for warfare can be also learned from the act that both superpowers from the Cold War era produced and stockpiled large number of weapons based on B. anthracis. The danger coming from B. anthracis used for a bioterrorist purpose can also be learned from the case of so called Anthrax letters in $2001(10,11)$.

In this review, a survey of actual literature on B. anthracis and the disease anthrax is provided and the mechanism of anthrax pathological effect, medical countermeasures and the threat coming from its misuse as biological warfare agent is surveyed. The aim is also to summarize and describe the relationship between the recent findings and progress in research on anthrax disease. 
Tab. 1. Basic specifications of Bacillus anthracis.

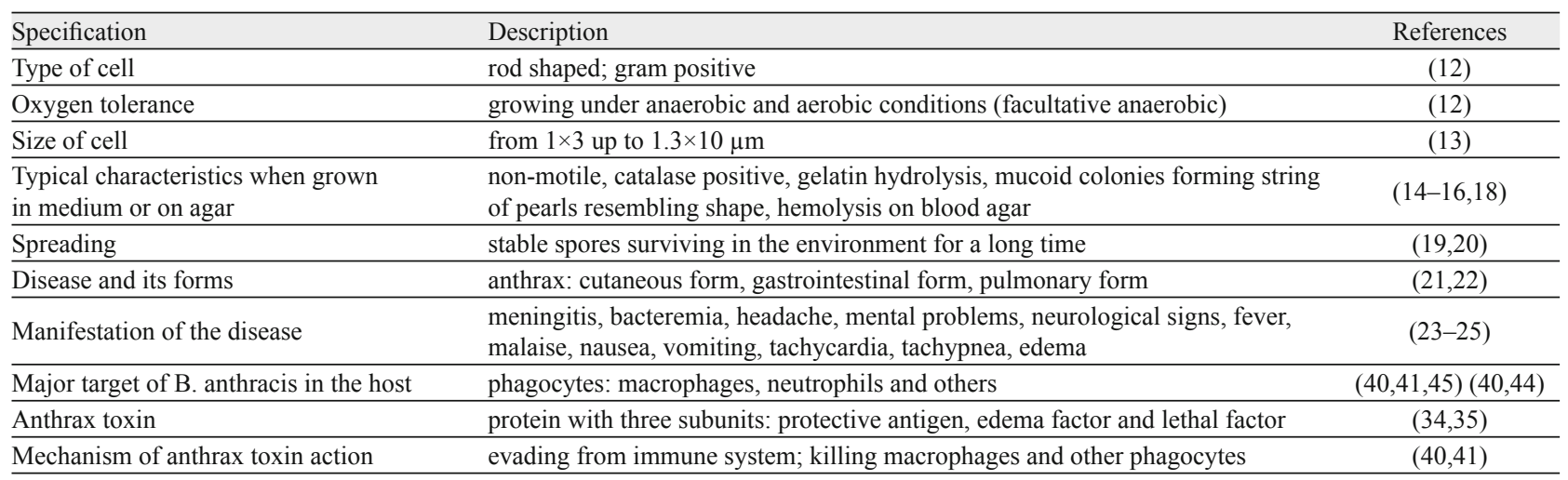

\section{Bacillus anthracis: a causative agent of anthrax}

B. anthracis is a rod shaped gram positive bacterium forming spores growing under both anaerobic and aerobic conditions (12). The cells of B. anthracis are rod shaped and quite large with the size variation of the rods from $1 \times 3$ up to $1.3 \times 10 \mu \mathrm{m}(13)$. The microorganism is non-motile in semi-solid media and it is also catalase positive, these two specifications are used for microbiological identification (14-16). Horse blood agar can be used for the growth purpose, but agar based on polymyxin, lysozyme, ethylenediaminetetraacetic acid and thallous acetate (known as PLET agar) is also suitable (17). Hemolysis on $5 \%$ sheep blood agar, gelatin hydrolysis and mucoid colonies on agar in form of string of pearls are another characteristic signs for B. anthracis (18). Spreading of B. anthracis is possible by its spores that exert enormous resistibility to the ambient environment and can persist in soil, water etc. for a long time $(19,20)$. The long-term stability and resistibility of the spores contribute to its virulence and they are significant properties making this microorganism a relevant threat, when misused for biological warfare purposes. Important specifications of B. anthracis are given in the Table 1 .

B. anthracis is a causative agent of anthrax disease, which is a zoonosis manifested in various forms. Cutaneous form starts, when spores or cells penetrate skin; gastrointestinal form follows ingestion of cells or spores and pulmonary form is the last and the most lethal type of anthrax following inhalation of spores or cells $(21,22)$. Each of the anthrax forms can lead to a very serious meningitis and bacteremia (23). The meningitis is typical for at least one third of patients and is manifested by a severe headache, mental problems and other related neurological signs (24). A detailed manifestation of anthrax can be learned from the work by Chen and coworkers, where fever, malaise, nausea, vomiting, tachycardia, tachypnea and mild edema were described (25). Apart from the above mentioned forms of anthrax, serious anthrax disease with a high bacteremia can start under specific conditions as a consequence of contaminated surgery tools and other similar invasive tools kept in an insufficient purity. Heroin associated anthrax epidemic can be mentioned as an example of potential problems caused by contaminated needles (26).
The ability of B. anthracis to survive in the host organism and the lethality of the infection is supported by production of anthrax toxin. The production of anthrax toxin is a substantial condition for germination of anthrax spores and progression of the anthrax disease (27). Hosts express anthrax toxin receptor, which is a cellular transmembrane protein naturally involved in angiogenesis, cell migration, skin elasticity and other functions to keep homeostasis (28-30). In reality, two proteins, tumor endothelium marker-8 and capillary morphogenesis protein-2, stand behind the name anthrax toxin receptor (31-33). Anthrax toxin is a protein with three subunits each having specific task in toxicokinetics and toxicodynamics. Protective antigen, edema factor and lethal factor are distinguished (34-36). The individual protein subunits are not toxic, but all the subunits together form the toxicity (37-39). While protective antigen is responsible for stabilization, hiding before the host immune system and transfer, edema factor is an adenylate cyclase producing cAMP to abnormal levels and in the final consequence causing disbalance in the host cell and evading the immune system. Lethal factor is a zinc dependent endoprotease, which interferes with signaling pathways and finally damages the cells. Macrophages are the major target for the both anthrax toxin and the microorganism itself (40-42). Lethal factor of anthrax toxin namely deactivates ERK (a group of Extracellular Signal-Related Kinases), p38 Mitogen Activated Protein Kinases (a group of kinases known under acronym MAPK) and c Jun N-terminal kinase by their proteolysis (43). B. anthracis can grow in the other phagocytes as well. Neutrophils are for instance another target of this pathogen $(40,44)$.

Apart from the anthrax toxin, other factors are irreplaceable for the ability to survive within macrophage cell. Production of nitric oxide is another key quality of B. anthracis and the produced nitric oxide contributes to killing of macrophages by S-nitrosylation of proteins, necessary for macrophage metabolism (45). Spores of $B$. anthracis must stand harsh conditions and germinate there. Activation of specific genes like yhgC (46) and protection from superoxide in phagosomes (47) are substantial for the bacterium survivability. Acquiring of necessary nutrients from the ambient environment is another specification of $B$. anthracis to germinate the spores (48). Once the bacterium suppresses the host cell, it spreads itself over the organism. While the infected host cells perish, bacterial burden increases and bacteremia is detectable and 


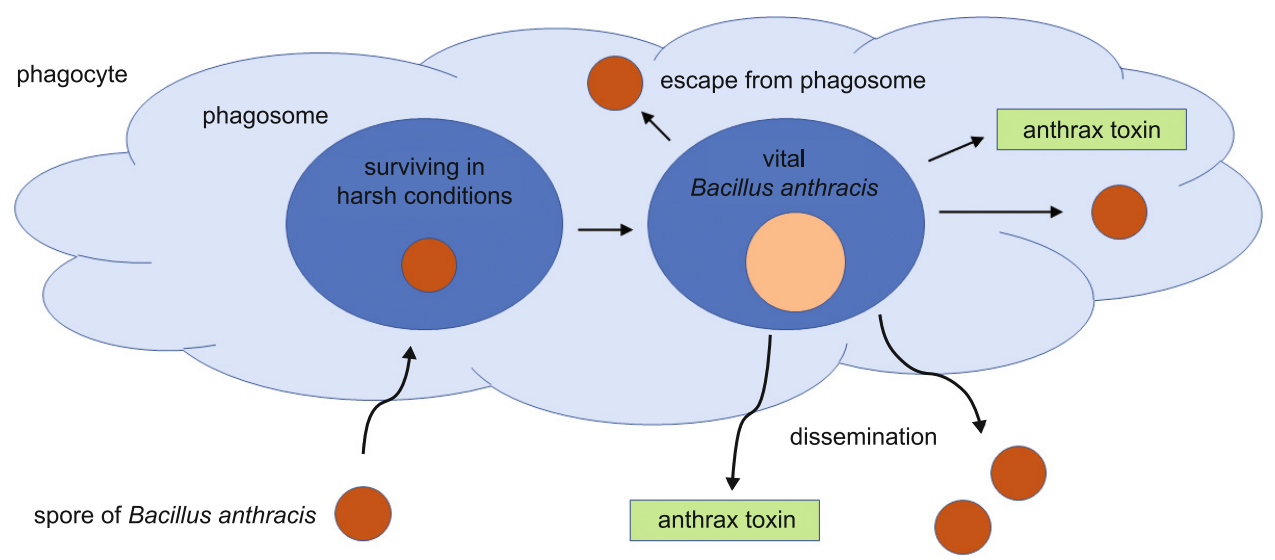

Fig. 1. Life cycle of B. anthracis and its interaction with host cell.

systematic spreading of infection follows, when the therapy is not sufficient or immune system not strong enough (49). B. anthracis also acquires nutrients at the expense of host. Proteolysis of human hemoglobin and acquiring of the liberated amino acids is another impact of anthrax on host organism (50). Scheme of B. anthracis life cycle and its interaction with host is depicted in the Figure 1.

\section{Anthrax therapy}

There are more approaches to reduce anthrax impact and both prophylactics as well as therapeutic means are available. The infection can be resolved under standard conditions by antibiotics. Amoxicillin, doxycycline, ciprofloxacin and penicillin G are recommended as the prime choice for chemotherapy of anthrax (51). The occurrence of $B$. anthracis strains resistant to the standard antibiotics like ciprofloxacin results in the necessity to investigate and introduce combination of antibiotics (52). Research on new derivatives of the common antibiotics like tetracycline derivative omadacycline (53) and aminomethyl spectinomycins (54) is ongoing. Antibiotics are also applicable for the prophylaxis of anthrax and they can be employed as a cost effective measure preceding anthrax epidemic in emergency situations (55-57). Overview of anthrax therapies are given in the Table 2.

Mortality caused by anthrax would be reduced by blocking the anthrax toxin. Though the idea appears quite promising, the efficacy is not so high to replace standard antibiotics. The effect of antibodies specific to protective antigen of anthrax toxin was investigated by Tournier and coworkers (58). The authors dis- cussed the effects of the antibody-based therapy and problems with evaluation of the therapy efficacy using an animal model. Testing of a new drug called Obiltoxaximab, which is a chimeric monoclonal antibody against protective antigen of anthrax toxin proved some effect and improved the chance to survive the infection (59-62). The drug is under clinical trials. Its effect can be further improved by combination with standard antibiotics. Comparing to the standard antibiotics, the therapy by antibodies against anthrax toxin can be employed for prophylactic purposes because patients can exert good tolerability to such therapy. The applied antibodies can be specific to edema and lethal factor of anthrax toxin and the neutralization of the whole toxin is principle of the therapy $(63,64)$. Antigen binding synthetic fragment of an antibody with a high affinity to edema factor appears promising (63). Combination of an antibiotics with an antitoxin (antibody specific to anthrax toxin) is recommended as a highly effective way how to protect from anthrax (65).

Active vaccination is not a therapeutic process, when the infection already starts but it is an effective tool for either avoiding or at least ameliorating the disease progression. The parts of anthrax toxin, such as protective antigen, spore specific antigens and inactivated spores can be chosen for vaccination purpose (66, 67). Commercial Anthrax Vaccine Licensed containing culture supernatant of a non-encapsulated strain producing toxin is effective for eliciting antibodies response. Current research is focused on production of vaccines containing recombinant proteins like Near-Iron Transporter having a good efficacy in the immunization of tested animals (68). The vaccination has also its limits. For

Tab. 2. Basic therapies for anthrax.

\begin{tabular}{ll}
\hline $\begin{array}{l}\text { Type of therapy } \\
\text { antibiotics }\end{array}$ & Drug \\
\hline $\begin{array}{l}\text { application of antibodies against } \\
\text { protective antigen of anthrax toxin }\end{array}$ & Standard drugs: amoxicillin, doxycycline, ciprofloxacin, penicillin G and others \\
$\begin{array}{l}\text { application of antibodies against edema } \\
\text { factor of anthrax toxin }\end{array}$ & fragment of a synthetic antibody \\
\hline $\begin{array}{l}\text { vaccination } \\
\text { immunization by parts of anthrax toxin, spore specific antigens and inactivated } \\
\text { spores, commercially available Anthrax Vaccine Licensed containing culture } \\
\text { supernatant of a non-encapsulated strain producing toxin }\end{array}$ \\
\hline
\end{tabular}




\section{5-181}

instance, Glinert and coworkers tested a protective antigen based vaccine and found that it was effective against subcutaneous spore challenge but the efficacy was limited for systemic challenges like intravenous application of virulent strains or mutants with deficient anthrax toxin (65). Therapies of infectious diseases can be further improved by nanoparticles serving like drug carriers, supporting material for antigen presentation during vaccination or material releasing antibiotics for a wider time span (69-76). Though there are no relevant studies on anthrax, the applicability of nanoparticles in the therapy can be inferred for the future.

\section{Diagnosis and detection techniques}

Determination of a biological warfare agent or a causative agent of an infection is an important step during emergency situations. Either a direct recognition of the microorganism and/or toxin or recognition of markers can be used in revealing of an attack by biological warfare agent like anthrax. A successful diagnosis confirmed by identification of the causative microorganism is the best situation and afterwards an optimal therapy can be chosen.

The microorganism itself can be differentiated from the other microorganism by the aforementioned cultivation tests. Though the cultivation is a standard method and it is necessary for confirmation of results, it has limited use for first response countermeasures because the cultivation protocols take one or two days. Simple devices like various hand-held devices, biosensors etc. are suitable for direct detection of B. anthracis spores or grown cells. Hand-held devices working on the principle of lateral flow immunochromatography assay are quite popular due to price, simplicity, portability and no need of an instrumentation because a coloration is evaluated by a naked eye and they also appears to be suitable for detection of anthrax cells, spores, antigens or anthrax toxin (3, $77,78)$. They can be also employed for the diagnosis of the disease by specific antibodies assay (79). There is also an advantage that more biological warfare agents can be determined in a single step. The device called Pro Strip by Advnt Biotechnologies, LLC (Phoenix, AZ, USA) is for instance able to contemporary detect Bacillus anthracis with limit of detection $1.5 \times 10^{4}-8.3 \times 10^{8}$ cells or spores per $\mathrm{ml}$, ricin with limit of detection $10 \mathrm{ng} / \mathrm{ml}$, botulinum toxin with limit of detection 33-500 ng/ml, Yersinia pestis with limit of detection $10^{5}$ cells $/ \mathrm{ml}$, and staphylococcal enterotoxin $B$ with limit of detection $10 \mathrm{ng} / \mathrm{ml}$ in an assay lasting 15 minutes. A single channel version of the before mentioned is called Biowarfare Agent Device. Its limit of detection for the single biological warfare agents and time per assay are the same as in the previous case. Another company, Alexeter Technologies (Wheeling, IL,
USA), make devices working on lateral flow immunochromatography assay principle as well. Their RAID 5 and RAID 8 devices are able to contemporary measure five respective eight biological warfare agents. The manufacturer exerts the limit of detection $10^{8}$ spores $/ \mathrm{ml}$ for B. anthracis. As seen from the aforementioned examples, lateral flow immunochromatography assay is a method for the detection of wide number of biological warfare agents. On the other hand, the limits of detection are quite high and they are not able to recognize low number of vital microorganism or spores, which are still dangerous for humans and able to initiate development of disease. In the current time, there is an effort to introduce biosensor devices to be an alternative to the standard bioassays, for instance optical and electrochemical biosensor for the detection of B. anthracis are developed (80-83). There is also a development of simple analytical tools allowing identification of $B$. anthracis by measurement of a specific metabolic reaction. It can be depicted on the work by Robinson and Bishop, who prepared the gel releasing fluorescent methylumbelliferone by enzymatic activity of $\alpha$-glucosidase from $B$. anthracis spores, when the microorganism is presented in tested sample (84). The simple disposable gel is able to disclose as low as $5 \times 10^{4} \mathrm{CFU}$ stuck on reaction test well with square $0.32 \mathrm{~cm}^{2}$.

In the standard laboratory praxis, there is a typical identification of B. anthracis based on characterization of their DNA and polymerase chain reaction (PCR) method is the most common. PCR can be of course used for the determination of microorganism isolates in vital form as well as spores, B. anthracis cells in swabs used for surface stirring, environment samples like soil, but it can be also employed for determination of viable cells and spores in clinical samples (85-90). Because PCR amplify DNA from a collected sample, one cell or spore can be theoretically determined by this method. Chromatography with a simple detector and combination of chromatography and mass spectrometry are universal analytical methods suitable for the determination of wide number of analytes. They can be used for measurement of specific antigens like glycoproteins on B. anthracis (91) and anthrax toxin (92-94).

Both antibodies specific to $B$. anthracis and antigens from B. anthracis itself can be recognized by standard immunochemical tests like Enzyme-Linked Immunosorbent Assay (ELISA). Though the assay is a standard one and it may appear that there is no improvement in this, the contrary is true because new types of antibodies and antigens are prepared resulting in better analytical properties than exert the predecessor assays. Even standard ELISA has quite good analytical properties including a very low falsepositivity and false-negativity $(95,96)$. Varshney and coworkers, for instance, prepared ELISA based on chimera protein contain-

Tab. 3. Overview of analytical and diagnostic methods for anthrax respective $B$. anthracis.

\begin{tabular}{|c|c|c|}
\hline Principle of assay & Detected part of B. anthracis or marker & References \\
\hline Lateral flow immunochromatography assay & whole cell or spore - limit of detection around millions of spores per milliliter & $(3,77,78)$ \\
\hline Polymerase chain reaction $(\mathrm{PCR})$ & $\begin{array}{l}\text { whole cell or spore in clinical or environmental samples, theoretically one cell } \\
\text { or spore can be detected }\end{array}$ & $(85-90)$ \\
\hline Chromatography and/or mass spectrometry & specific antigens like glycoproteins, anthrax toxin & $(91-93)$ \\
\hline $\begin{array}{l}\text { Enzyme-Linked Immunosorbent Assay } \\
\text { (ELISA) }\end{array}$ & $\begin{array}{l}\text { antibodies specific to B. anthracis from a host organism and antigens from } \\
\text { B. anthracis }\end{array}$ & $(95-99)$ \\
\hline
\end{tabular}


ing parts of protective antigen and lethal factor of anthrax toxin expressed in Escherichia coli (97). This ELISA served for anthrax diagnosis by recognition of specific antibodies against the parts of anthrax toxin. The use of recombinant proteins as a platform for revealing the antibodies against $\mathrm{B}$. anthracis by ELISA was also chosen in the work by Simbotwe and coworkers (98) and Ghosh and coworkers (99). Methods like various fluorescent immunosorbent assays (100) or enzyme linked immunospot (101) are functional alternatives to the standard ELISA (Tab. 3).

\section{Conclusions}

B. anthracis is a serious threat, when misused for military or terrorist activities. It can cause a lethal impact on human population even though therapies and prophylactic countermeasures are available. In the current approach, a proper diagnosis of the disease, timely recognition of causative agent, prophylaxis of personnel providing help and a suitable therapy to the victims are the crucial steps. Further improvements of the diagnostic and detection platform are necessary. Effective passive and active vaccines are also highly desired. Though antibiotics are available and effective for therapy, further research on the new drugs with minimal side effect could bring an opportunity to protect general population with minimal harm in the case of false positive report of an anthrax attack and a good efficacy of therapy in the case of real emergency situation.

\section{References}

1. Janik E, Ceremuga M, Saluk-Bijak J, Bijak M. Biological toxins as the potential tools for bioterrorism. Int J Mol Sci 2019; 20 (5).

2. Kwon EH, Reisler RB, Cardile AP et al. Distinguishing respiratory features of category a/b potential bioterrorism agents from communityacquired pneumonia. Health Secur 2018; 16 (4): 224-238.

3. Pohanka M. Current trends in the biosensors for biological warfare agents assay. Materials 2019; 12 (14): E2303.

4. Balali-Mood M, Moshiri M et al. Medical aspects of bio-terrorism. Toxicon 2013; 69: 131-142.

5. Thavaselvam D, Vijayaraghavan R. Biological warfare agents. J Pharm Bioallied Sci 2010; 2 (3): 179-188.

6. Snopkova S, Pohanka M, Polak P et al. Acute toxoplasmosis-etiological factor for development of hodgkin's lymphoma? Scand J Infect Dis 2013; 45 (12): 953-956.

7. Kumar A. Hiv and substance abuse. Curr HIV Res 2012; 10 (5): 365-365.

8. Tumban E. A current update on human papillomavirus-associated head and neck cancers. Viruses 2019; 11 (10).

9. Rojas-Celis V, Valiente-Echeverria F, Soto-Rifo R, Toro-Ascuy D. New challenges of hiv-1 infection: How hiv-1 attacks and resides in the central nervous system. Cells 2019; 8 (10).

10. Zink TK. Anthrax attacks: Lessons learned on the 10th anniversary of the anthrax attacks. Disaster Med Public Health Prep 2011; 5 (3): 173-174.

11. Zacchia NA, Schmitt K. Medical spending for the 2001 anthrax letter attacks. Disaster Med Public Health Prep 2019; 13 (3): 539-546.
12. Drobniewski FA. Bacillus cereus and related species. Clin Microbiol Rev 1993; 6 (4): 324-338.

13. Salton MRJ, Kim KS. Structure. University of Texas: Texas, 1996.

14. Angelety LH, Wright GG. Agar diffusion method for the differentiation of bacillus anthracis. Appl Microbiol 1971; 21 (1): 157-159.

15. Rahi A, Rehan M, Garg R, Tripathi D, Lynn AM, Bhatnagar R. Enzymatic characterization of catalase from bacillus anthracis and prediction of critical residues using information theoretic measure of relative entropy. Biochem Biophys Res Commun 2011; 411 (1): 88-95.

16. Tu WY, Pohl S, Summpunn P, Hering S, Kerstan S, Harwood CR. Comparative analysis of the responses of related pathogenic and environmental bacteria to oxidative stress. Microbiology 2012; 158 (Pt 3): 636-647.

17. Papaparaskevas J, Houhoula DP, Papadimitriou M, Saroglou G, Legakis NJ, Zerva L. Ruling out bacillus anthracis. Emerg Infect Dis 2004; 10 (4): 732-735.

18. Jula GM, Sattari M, Banihashemi R, Razzaz H, Sanchouli A, Tadayon K. The phenotypic and genotypic characterization of bacillus anthracis isolates from iran. Trop Anim Health Prod 2011; 43 (3): 699-704.

19. Carlson CJ, Getz WM, Kausrud KL et al. Spores and soil from six sides: Interdisciplinarity and the environmental biology of anthrax (bacillus anthracis). Biol Rev Camb Philos Soc 2018; 93 (4): 1813-1831.

20. Swick MC, Koehler TM, Driks A. Surviving between hosts: Sporulation and transmission. Microbiol Spectr 2016; 4 (4): 0029-2015.

21. Kumar BV, Malik S, Grandhi P, Dayam R, Sarma JA. Anthrax lethal factor inhibitors as potential countermeasure of the infection. Curr Top Med Chem 2014; 14 (17): 1977-1989.

22. Weiner ZP, Glomski IJ. Updating perspectives on the initiation of bacillus anthracis growth and dissemination through its host. Infect Immun 2012; 80 (5): 1626-1633.

23. Berger T, Kassirer M, Aran AA. Injectional anthrax - new presentation of an old disease. Euro Surveill 2014; 19 (32): 1560-7917.

24. Katharios-Lanwermeyer S, Holty JE, Person M et al. Identifying meningitis during an anthrax mass casualty incident: Systematic review of systemic anthrax since 1880. Clin Infect Dis 2016; 62 (12): 1537-1545.

25. Chen H, Bao W, Wang Y, Zhang K, Wang F. Clinical and epidemiological investigation of a fatal anthrax case in china. J Infect Dev Ctries 2015; 9 (2): 214-217.

26. Abbara A, Brooks T, Taylor GP et al. Lessons for control of heroinassociated anthrax in europe from 2009-2010 outbreak case studies, london, uk. Emerg Infect Dis 2014; 20 (7): 1115-1122.

27. Guidi-Rontani C, Levy M, Ohayon H, Mock M. Fate of germinated bacillus anthracis spores in primary murine macrophages. Mol Microbiol 2001; 42 (4): 931-938.

28. Sergeeva OA, Goot FG. Converging physiological roles of the anthrax toxin receptors. F1000Res 2019; 8: F1000.

29. Bradley KA, Young JA. Anthrax toxin receptor proteins. Biochem Pharmacol 2003; 65 (3): 309-314.

30. Scobie HM, Rainey GJ, Bradley KA, Young JA. Human capillary morphogenesis protein 2 functions as an anthrax toxin receptor. Proc Natl Acad Sci USA 2003; 100 (9): 5170-5174.

31. Liu S, Zhang Y, Hoover B, Leppla SH. The receptors that mediate the direct lethality of anthrax toxin. Toxins $2012 ; 5$ (1): 1-8. 
32. Chen KH, Liu S, Leysath CE et al. Anthrax toxin protective antigen variants that selectively utilize either the cmg2 or tem8 receptors for cellular uptake and tumor targeting. J Biol Chem 2016; 291 (42): 22021-22029.

33. Chen KH, Liu S, Bankston LA, Liddington RC, Leppla SH. Selection of anthrax toxin protective antigen variants that discriminate between the cellular receptors tem8 and cmg2 and achieve targeting of tumor cells. J Biol Chem 2007; 282 (13): 9834-9845.

34. Lahousse M, Park HC, Lee SC et al. Inhibition of anthrax lethal factor by ssdna aptamers. Arch Biochem Biophys 2018; 646: 16-23.

35. Lee SC, Gedi V, Ha NR, Cho JH, Park HC, Yoon MY. Development of receptor-based inhibitory rna aptamers for anthrax toxin neutralization. Int J Biol Macromol 2015; 77: 293-302.

36. Kondakova OA, Nikitin NA, Evtushenko EA, Ryabchevskaya EM, Atabekov JG, Karpova OV. Vaccines against anthrax based on recombinant protective antigen: Problems and solutions. Expert Rev Vaccines 2019; 18 (8): 813-828.

37. Vuyisich M, Sanders CK, Graves SW. Binding and cell intoxication studies of anthrax lethal toxin. Mol Biol Rep 2012; 39 (5): 5897-5903.

38. Friebe S, van der Goot FG, Burgi J. The ins and outs of anthrax toxin. Toxins 2016; 8 (3).

39. Mikshis NI, Popova P, Kudriavtseva OM, Goncharova A, Popov Iu A, Kutyrev VV. Immunogenicity of protective antigen extracted from asporogenic recombinant strain bacillus anthracis. Zh Mikrobiol Epidemiol Immunobiol 2011; 1: 44-48.

40. Liu JZ, Ali SR, Bier E, Nizet V. Innate immune interactions between bacillus anthracis and host neutrophils. Front Cell Infect Microbiol 2018; 8 (2).

41. Pan Z, Dumas EK, Lawrence $C$ et al. Bacillus anthracis edema toxin inhibits efferocytosis in human macrophages and alters efferocytic receptor signaling. Int J Mol Sci 2019; 20 (5).

42. Pantha B, Cross A, Lenhart S, Day J. Modeling the macrophageanthrax spore interaction: Implications for early host-pathogen interactions. Math Biosci 2018; 305: 18-28.

43. Ngai S, Batty S, Liao KC, Mogridge J. An anthrax lethal factor mutant that is defective at causing pyroptosis retains proapoptotic activity. Febs J 2010; 277 (1): 119-127.

44. Drysdale M, Olson G, Koehler TM, Lipscomb MF, Lyons CR. Murine innate immune response to virulent toxigenic and nontoxigenic bacillus anthracis strains. Infect Immun 2007; 75 (4): 1757-1764.

45. Chung MC, Narayanan A, Popova TG, Kashanchi F, Bailey CL, Popov SG. Bacillus anthracis-derived nitric oxide induces protein s-nitrosylation contributing to macrophage death. Biochem Biophys Res Commun 2013; 430 (1): 125-130.

46. Kiran MD, Bala S, Hirshberg M, Balaban N. Yhgc protects bacillus anthracis from oxidative stress. Int J Artif Organs 2010; 33 (9): 590-607.

47. Baillie L, Hibbs S, Tsai P, Cao GL, Rosen GM. Role of superoxide in the germination of bacillus anthracis endospores. FEMS Microbiol Lett 2005; 245 (1): 33-38.

48. Honsa ES, Maresso AW. Mechanisms of iron import in anthrax. Biometals 2011; 24 (3): 533-545.

49. Glinert I, Weiss S, Sittner A et al. Infection with a nonencapsulated bacillus anthracis strain in rabbitsthe role of bacterial adhesion and the potential for a safe live attenuated vaccine. Toxins 2018; 10 (12).

50. Terwilliger A, Swick MC, Pflughoeft KJ et al. Bacillus anthracis overcomes an amino acid auxotrophy by cleaving host serum proteins. J Bacteriol 2015; 197 (14): 2400-2411.
51. Manzulli V, Fasanella A, Parisi A et al. Evaluation of in vitro antimicrobial susceptibility of bacillus anthracis strains isolated during anthrax outbreaks in italy from 1984 to 2017. J Vet Sci 2019; 20 (1): 58-62.

52. Heine HS, Shadomy SV, Boyer AE et al. Evaluation of combination drug therapy for treatment of antibiotic-resistant inhalation anthrax in a murine model. Antimicrob Agents Chemother 2017; 61 (9): 00788-00717.

53. Watkins RR, Deresinski S. Omadacycline: A novel tetracycline derivative with oral and intravenous formulations. Clin Infect Dis 2019; 69 (5): 890-896.

54. Scarff JM, Waidyarachchi SL, Meyer CJ et al. Aminomethyl spectinomycins: A novel antibacterial chemotype for biothreat pathogens. J Antibiot 2019; 72 (9): 693-701.

55. Fowler RA, Sanders GD, Bravata DM et al. Cost-effectiveness of defending against bioterrorism: A comparison of vaccination and antibiotic prophylaxis against anthrax. Ann Intern Med 2005; 142 (8): 601-610.

56. Kyriacou DN, Dobrez D, Parada JP et al. Cost-effectiveness comparison of response strategies to a large-scale anthrax attack on the chicago metropolitan area: Impact of timing and surge capacity. Biosecur Bioterror 2012; 10 (3): 264-279.

57. Schmitt B, Dobrez D, Parada JP et al. Responding to a small-scale bioterrorist anthrax attack: Cost-effectiveness analysis comparing preattack vaccination with postattack antibiotic treatment and vaccination. Arch Intern Med 2007; 167 (7): 655-662.

58. Tournier JN, Rougeaux C, Biot FV, Goossens PL. Questionable efficacy of therapeutic antibodies in the treatment of anthrax. mSphere 2019; 4 (3): 00282-00219.

59. Henning LN, Carpenter S, Stark GV, Serbina NV. Development of protective immunity in new zealand white rabbits challenged with bacillus anthracis spores and treated with antibiotics and obiltoxaximab, a monoclonal antibody against protective antigen. Antimicrob Agents Chemother 2018; 62 (2): e01590-01517.

60. Yamamoto BJ, Shadiack AM, Carpenter S et al. Obiltoxaximab prevents disseminated bacillus anthracis infection and improves survival during pre- and postexposure prophylaxis in animal models of inhalational anthrax. Antimicrob Agents Chemother 2016; 60 (10): 5796-5805.

61. Yamamoto BJ, Shadiack AM, Carpenter $S$ et al. Efficacy projection of obiltoxaximab for treatment of inhalational anthrax across a range of disease severity. Antimicrob Agents Chemother 2016; 60 (10): 5787-5795.

62. Nagy CF, Leach TS, King A, Guttendorf R. Safety, pharmacokinetics, and immunogenicity of obiltoxaximab after intramuscular administration to healthy humans. Clin Pharmacol Drug Dev 2018; 7 (6): 652-660.

63. Farcasanu M, Wang AG, Uchanski T et al. Rapid discovery and characterization of synthetic neutralizing antibodies against anthrax edema toxin. Biochemistry 2019; 58 (27): 2996-3004.

64. Zhou B, Carney C, Janda KD. Selection and characterization of human antibodies neutralizing bacillus anthracis toxin. Bioorg Med Chem 2008; 16 (4): 1903-1913.

65. Glinert I, Bar-David E, Sittner A et al. Revisiting the concept of targeting only bacillus anthracis toxins as a treatment for anthrax. Antimicrob Agents Chemother 2016; 60 (8): 4878-4885.

66. Ndumnego OC, Koehler SM, Crafford JE, Beyer W, van Heerden H. Immunogenicity of anthrax recombinant peptides and killed spores in goats and protective efficacy of immune sera in a/j mouse model. Sci Rep 2018; 8.

67. Dumas EK, Gross T, Larabee J et al. Anthrax vaccine precipitated induces edema toxin-neutralizing, edema factor-specific antibodies in human recipients. Clin Vaccine Immunol 2017; 24 (11). 
68. Balderas MA, Nguyen CTQ, Terwilliger A et al. Progress toward the development of a neat protein vaccine for anthrax disease. Infect Immun 2016; 84 (12): 3408-3422.

69. Pohanka M. Copper and copper nanoparticles toxicity and their impact on basic functions in the body. Bratisl Med J 2019; 120 (6): 397-409.

70. Pohanka M. Quantum dots in the therapy: Current trends and perspectives. Mini Rev Med Chem 2017; 20: 20.

71. Labruere R, Sona AJ, Turos E. Anti-methicillin-resistant staphylococcus aureus nanoantibiotics. Front Pharmacol 2019; 10 (1121).

72. Abo-Zeid Y, Williams GR. The potential anti-infective applications of metal oxide nanoparticles: A systematic review. Wiley Interdiscip Rev Nanomed Nanobiotechnol 2019; 8 (10).

73. Acharya R. The recent progresses in shrna-nanoparticle conjugate as a therapeutic approach. Mater Sci Eng C Mater Biol Appl 2019; 104 (109928): 27.

74. Rozman NAS, Tong WY, Leong CR, Tan WN, Hasanolbasori MA, Abdullah SZ. Potential antimicrobial applications of chitosan nanoparticles (chnp). J Microbiol Biotechnol 2019; 29 (7): 1009-1013.

75. Cheng CA, Deng T, Lin FC, Cai Y, Zink JI. Supramolecular nanomachines as stimuli-responsive gatekeepers on mesoporous silica nanoparticles for antibiotic and cancer drug delivery. Theranostics 2019; 9 (11): 3341-3364.

76. Kumar N, Chen W, Cheng CA, Deng T, Wang R, Zink JI. Stimuliresponsive nanomachines and caps for drug delivery. Enzymes 2018; 43: $31-65$.

77. Bartholomew RA, Ozanich RM, Arce JS et al. Evaluation of immunoassays and general biological indicator tests for field screening of bacillus anthracis and ricin. Health Secur 2017; 15 (1): 81-96.

78. Kolton CB, Marston CK, Stoddard RA et al. Detection of bacillus anthracis in animal tissues using inbios active anthrax detect rapid test lateral flow immunoassay. Lett Appl Microbiol 2019; 68 (6): 480-484.

79. Biagini RE, Sammons DL, Smith JP et al. Rapid, sensitive, and specific lateral-flow immunochromatographic device to measure anti-anthrax protective antigen immunoglobulin $\mathrm{g}$ in serum and whole blood. Clin Vaccine Immunol 2006; 13 (5): 541-546.

80. Luo Y, Zhang L, Yu B, Wang Y, Zhang W. Multiporous terbium phosphonate coordination polymer microspheres as fluorescent probes for trace anthrax biomarker detection. ACS Appl Mater Interfaces 2019; 11 (17): 15998-16005.

81. Rong $M$, Yang $X$, Huang $L$ et al. Hydrogen peroxide-assisted ultrasonic synthesis of beno qds for anthrax biomarker detection. ACS Appl Mater Interfaces 2019; 11 (2): 2336-2343.

82. Mazzaracchio V, Neagu D, Porchetta A et al. A label-free impedimetric aptasensor for the detection of bacillus anthracis spore simulant. Biosens Bioelectron 2019; 126: 640-646.

83. Chen P, Gates-Hollingsworth M, Pandit S et al. Paper-based vertical flow immunoassay (vfi) for detection of bio-threat pathogens. Talanta 2019; 191: 81-88.

84. Robinson CV, Bishop AH. A disclosure gel for visual detection of live bacillus anthracis spores. J Appl Microbiol 2019; 126 (6): 1700-1707.

85. Drago L, Lombardi A, Vecchi ED, Gismondo MR. Real-time per assay for rapid detection of bacillus anthracis spores in clinical samples. J Clin Microbiol 2002; 40 (11).
86. Makino S, Cheun HI. Application of the real-time pcr for the detection of airborne microbial pathogens in reference to the anthrax spores. $\mathrm{J}$ Microbiol Methods 2003; 53 (2): 141-147.

87. Makino SI, Cheun HI, Watarai M, Uchida I, Takeshi K. Detection of anthrax spores from the air by real-time pcr. Lett Appl Microbiol 2001; 33 (3): 237-240.

88. Cheun HI, Makino SI, Watarai M, Erdenebaatar J, Kawamoto K, Uchida I. Rapid and effective detection of anthrax spores in soil by pcr. J Appl Microbiol 2003; 95 (4): 728-733.

89. Ryu C, Lee K, Yoo C, Seong WK, Oh HB. Sensitive and rapid quantitative detection of anthrax spores isolated from soil samples by real-time pcr. Microbiol Immunol 2003; 47 (10): 693-699.

90. Oggioni MR, Meacci F, Carattoli A et al. Protocol for real-time pcr identification of anthrax spores from nasal swabs after broth enrichment. J Clin Microbiol 2002; 40 (11): 3956-3963.

91. Fox A, Stewart GC, Waller LN, Fox KF, Harley WM, Price RL. Carbohydrates and glycoproteins of bacillus anthracis and related bacilli: Targets for biodetection. J Microbiol Methods 2003; 54 (2): 143-152.

92. Pasechnik VA, Shone CC, Hambleton P. Purification of bacterial exotoxins. The case of botulinum, tetanus, anthrax, pertussis and cholera toxins. Bioseparation 1992; 3 (5): 267-283.

93. Boyer AE, Gallegos-Candela M, Lins RC et al. Quantitative mass spectrometry for bacterial protein toxins--a sensitive, specific, highthroughput tool for detection and diagnosis. Molecules 2011; 16 (3): 2391-2413.

94. Lins RC, Boyer AE, Kuklenyik Z et al. Zeptomole per milliliter detection and quantification of edema factor in plasma by lc-ms $/ \mathrm{ms}$ yields insights into toxemia and the progression of inhalation anthrax. Anal Bioanal Chem 2019; 411 (12): 2493-2509.

95. Ghosh N, Tomar I, Lukka H, Goel AK. Serodiagnosis of human cutaneous anthrax in india using an indirect anti-lethal factor igg enzymelinked immunosorbent assay. Clin Vaccine Immunol 2013; 20 (2): 282-286.

96. Semenova VA, Schiffer J, Steward-Clark E et al. Validation and long term performance characteristics of a quantitative enzyme linked immunosorbent assay (elisa) for human anti-pa igg. J Immunol Methods 2012; 376 (1-2): 97-107.

97. Varshney A, Puranik N, Kumar M, Pal V, Padmaja J, Goel AK. An elisa using a recombinant chimera of protective antigen and lethal factor for serodiagnosis of cutaneous anthrax in india. Biologicals 2019; 57: 55-60.

98. Simbotwe M, Fujikura D, Ohnuma M et al. Development and application of a bacillus anthracis protective antigen domain-1 in-house elisa for the detection of anti-protective antigen antibodies in cattle in zambia. PLoS One 2018; 13 (10).

99. Ghosh N, Gunti D, Lukka H, Reddy BR, Padmaja J, Goel AK. Development \& validation of a quantitative anti-protective antigen igg enzyme linked immunosorbent assay for serodiagnosis of cutaneous anthrax. Indian J Med Res 2015; 142 (2): 196-204.

100. Biagini RE, Sammons DL, Smith JP et al. Comparison of a multiplexed fluorescent covalent microsphere immunoassay and an enzymelinked immunosorbent assay for measurement of human immunoglobuling antibodies to anthrax toxins. Clin Diagn Lab Immunol 2004; 11 (1): 50-55.

101. Bar-Haim E, Rotem S, Elia U et al. Early diagnosis of pathogen infection by cell-based activation immunoassay. Cells 2019; 8 (9). 